九州大学学術情報リポジトリ

Kyushu University Institutional Repository

Selection of a Vegetable Water-Retaining

Material and Its Effects on the Growth and Quality of Cucumber under Drought Stress Part 1 : Selection of a Vegetable Water-Retaining Material

Yang, Shang-Dong

College of Agriculture, Guangxi University

Wang, Rui

College of Agriculture, Guangxi University

Li, Gang

College of Agriculture, Guangxi University

Egashira, Kazuhiko

Department of Plant Resources, Faculty of Agriculture, Kyushu University

https://doi.org/10.5109/10083

出版情報：九州大学大学院農学研究院紀要. 53 (1)，pp.133-136，2008-02-28. Faculty of Agriculture, Kyushu University

バージョン：

権利関係 : 


\title{
Selection of a Vegetable Water-Retaining Material and Its Effects on the Growth and Quality of Cucumber under Drought Stress Part 1: Selection of a Vegetable Water-Retaining Material
}

\author{
Shang-Dong YANG ${ }^{1}$, Rui WANG ${ }^{1}$, Gang LI $^{1}$ and Kazuhiko EGASHIRA* \\ Laboratory of Soil Science, Division of Soil Science and Plant Production, \\ Department of Plant Resources, Faculty of Agriculture, \\ Kyushu University, Fukuoka 812-8581, Japan \\ (Received November 9, 2007 and accepted November 30, 2007)
}

\begin{abstract}
Water-retention capacities of moss, common water hyacinth and Late Juncellus were compared with that of SAP (super absorbent polymers), a presently used chemical water-retaining material. Moss was highest in the amount of water retained per unit weight among the three vegetable materials and showed a somewhat higher water-retention capacity than did SAP. However, it is difficult to collect moss enough for use as a water-retaining material, and collection of a large amount of moss easily lead to destruction of environment. Moss had a high potential but actually was not appropriate for using as a water-retaining material in crop production. Instead, common water hyacinth was targeted. It is an invading aquatic macrophyte with a potential for rapid growth and spreading, and has caused serious damage to local environment. Though its water-retention capacity was not so good as those of moss and SAP, common water hyacinth was easy to be collected and gave benefit to the soil water content and the growth of cucumber in the similar level as SAP. Results indicated that common water hyacinth could be used in the future as a vegetable water-retaining material.
\end{abstract}

\section{INTRODUCTION}

Water is the most limiting resource in agricultural production over the world. Drought has caused serious damage to crop growth and yield. Guangxi Province is located in the southern part of China and belongs to the tropical to subtropical monsoon zone. The whole province is alternatively subjected to the warm-wet oceanic climate and the northern cold climate with the longer summer season of higher temperature and greater rainfall and the shorter winter season of warm and dry weather. Rainfall amount is enough with an annual precipitation ranging between 1,100 and 2,600 $\mathrm{mm}$ but rainfall distribution is uneven. It is characterized by the larger rainfall amount in the spring and summer seasons (March to August) with 80\% of the whole precipitation and the smaller rainfall amount in the autumn and winter seasons (September to February) with only $20 \%$ of the whole precipitation.

Topographically, karst mountain is distributed in Guangxi Province in a large area. Cultivation of crops on the karst mountain area is hampered by drought due to shallow soil layer. However, it is difficult to construct an irrigation system on such a sloping land. It is a big problem how to supply water to crops, and hence it is an inevitable and urgent task to create a practical way to reduce damage by drought in Guangxi Province. Use of super absorbent polymers (SAP) is a way at present to solve this problem.

Super absorbent polymers (SAP) are chemical com-

\footnotetext{
Laboratory of Horticulture Science, Division of Horticulture Science and Plant Production, College of Agriculture, Guangxi University, Nanning, Guangxi Province, China 53004; E-mail address of the top author: yangshangdong@hotmail.com

* Corresponding author (E-mail: kegashi@agr.kyushu-u.ac.jp)
}

pounds that absorb water and swell many times of their original size and weight. SAP has been used to create a water reserve near roots in soil. (Li et al., 2001; Sun et al., 2001). SAP can be grouped into several types according to the raw material, form, and characteristic of hydrophilicity: (1) SAP is grouped by the raw material into types of starch (polyacrylamide, polyacetal), fiber (carboxymethyl cellulose, cellulose) and polymer (polyacrylonitrile, polyvinylalcohol); (2) SAP is grouped by the form into powder, flake, fiber, and liquid; (3) SAP is grouped by the characteristic of hydrophilicity into dissolvable and undissolvable types. Among them, polyacrylamide and polyacetal of the starch type are most widely used at present in agriculture.

However, it takes a long time for SAP to be biodegraded in soil owing to their high molecular weight and complex chemical composition. It may cause some environmental problem if SAP is applied continuously for long term. High cost of SAP is another problem in its comprehensive use. For example, the cost of SAP used in the present study was about 65 110 US dollars per hectare according to the price written in the instruction manual. It is difficult to extend use of SAP to the deprived area at such a high cost.

Therefore, it is necessary to develop a new kind of vegetable materials, which has the great water-retention capability and gives benefit to the environment. It should be cheap for use in agricultural production of the karst mountain area. Moss, common water hyacinth (Eichhornia crassipes) and Late Juncellus (Juncellus serotinus) are all growing in the wetland and easy to be reproduced. At the same time, they are all cheap to be collected and have some level of capability in retaining water. Therefore, they were examined as candidates of vegetable water-retaining materials in the present study. 
Because roots of cucumber are distributed in a shallow surface layer in soil, it is easily suffered from drought stress during growing. Even if cucumber was placed under drought stress for a short period, the fiber content in cucumber and the deformity rate will be obviously increased. Quality of cucumber is easily lowered under drought condition. As a result, cucumber can be considered a plant suitable for testing the water-retention capability of water-retaining materials.

\section{MATERIALS AND METHODS}

\section{Experimental site}

The laboratory test and pot experiment were conducted in the College of Agriculture, Guangxi University in Nanning City (N 22 $18^{\prime}$, E 107 $45^{\prime}$ ) of Guangxi Province, People's Republic of China. Nanning City is located at just south of the Tropic of Cancer. The city belongs to the sub-tropical monsoon zone, with plenty of sunshine, little frost and almost no snow, and is affected by the oceanic climate. The mean annual temperature is about $21.7^{\circ} \mathrm{C}$ and the mean annual precipitation is up to $1,300 \mathrm{~mm}$. (Committee of Guangxi Soil Investigation Group, 1994)

\section{Vegetable water-retaining materials}

Following three vegetable water-retaining materials were used : (1) moss; (2) common water hyacinth (Eichhornia crassipes); and (3) Late Juncellus (Juncellus serotinus). Moss was bought in market, and common water hyacinth and Late Juncellus were collected from the pond near Guangxi University and in the countryside of Nanning City, respectively. They were all dried at $70{ }^{\circ} \mathrm{C}$ in an oven and pulverized into powder by a mechanical grinder.

\section{Laboratory test on the water-retention capacity of water-retaining materials}

In laboratory, each $5 \mathrm{~g}$ powder of moss, common water hyacinth and Late Juncellus were weighed, put in a net bag and immersed in water for 10 minutes. The amount of adsorbed and retained water was measured by weighing them after taking out from water and standing at room temperature for one hour. SAP whose main component is polyacrylamide was bought in market and used as control. It was treated in the same way as vegetable water-retaining materials. The measurement was done in triplicate.

\section{Pot experiment on the effects of water-retaining materials on the soil water content and the height of cucumber}

The pot experiment was carried out under natural weather conditions in the greenhouse of the College of Agriculture, Guangxi University on April 2006. Cucumber of the variety of JinYan, bought in market, was used. Each pot was packed with $10 \mathrm{~kg}$ of red soil collected from the sugarcane farm of Guangxi University. Four types of water-retaining materials were put in a shallow furrow dug around cucumber stems followed by covering with soil.

Cultivation of cucumber, fertilization and droughtstress treatment in the pot experiment are described in detail in Part 2 of the study (Yang et al., 2008). After planting of two young seedlings of cucumber in a pot, watering was done almost every day with the same volume of water among the pots added with different water-retaining materials until rooting of cucumber seedlings was confirmed. Drought stress was imposed in the seedling stage of cucumber and watering was stopped for 7 to 10 days before measurement of the soil water content. However, stop of watering for 10 days was too strong as the drought treatment and some seedlings wilted to death.

Measurement of the soil water content was carried out by weighing soil sample before and after oven-drying at $105{ }^{\circ} \mathrm{C}$ (Committee of Standard Methods for Analysis and Measurement of Soil (ed), 1986). For this purpose soil was sampled from the depth of 0 to $20 \mathrm{~cm}$. The height of cucumber was measured at 20 days after planting by a tape measure from the soil surface to the apex of a plant. All measurements were done in triplicate.

\section{General soil analyses}

Fundamental chemical properties of the soil used in the pot experiment of Parts 1 (this study) and 2 (Yang et al., 2008) were measured mainly according to the soil standard methods of analysis (Committee of Standard Methods for Analysis and Measurement of Soil (ed), 1986). The organic carbon content was determined by the Tyurin method and was multiplied by the coefficient of 1.724 to give the organic matter content. The $\mathrm{pH}$ was measured in the suspension having a soil:water ratio of 1:2.5. The measurement was done in triplicate followed by taking the average.

\section{Statistical analyses}

Duncan's SSR test was used for the statistical analyses.

\section{RESULTS AND DISCUSSION}

\section{Soil and its fundamental chemical properties}

Red soil collected from the sugarcane farm of Guangxi University in Nanning City was used in the pot experiment for prevention from occurrence of soil-borne disease or happening of malfunction by cropping. Fundamental chemical properties of the soil are shown in Table 1. Only the organic matter content is listed for

Table 1. Fundamental chemical properties of the soil used in the pot experiment

\begin{tabular}{lcc}
\hline \multicolumn{1}{c}{ Item } & Value & Unit \\
\hline $\mathrm{pH}\left(\mathrm{H}_{2} \mathrm{O}\right)$ & 5.5 & \\
Electrical conductivity & 0.2 & $\mathrm{mS} \mathrm{cm}^{-1}$ \\
Available potassium & 71.2 & $\mathrm{mg} \mathrm{kg}^{-1}$ \\
Available phosphorus & 14.6 & $\mathrm{mg} \mathrm{kg}^{-1}$ \\
Cation-exchange capacity & 10.9 & $\mathrm{cmol}_{\mathrm{c}} \mathrm{kg}^{-1}$ \\
Organic matter & 14.5 & $\mathrm{~g} \mathrm{~kg}^{-1}$ \\
\hline
\end{tabular}


the soil subjected to the application of basal dressing of organic and chemical fertilizers (Yang et al., 2008). The organic matter content of the original soil was evaluated to be in the level of 2.0 to $3.0 \mathrm{~g} \mathrm{~kg}^{-1}$.

\section{Comparison of the water-retention capacities of vegetable water-retaining materials with that of SAP}

Results on the laboratory test on the water-retention capacity of water-retaining materials are shown in Table 2. A significant difference at the 1\% level in the amount of water retained per unit weight was observed between the water-retaining materials. It was highest for moss, followed by SAP, common water hyacinth and Late Juncellus in this sequence. The large difference in the amount of water retained was observed between the former two materials and the latter two materials. The amount of water retained by moss was higher by $12 \%$ than that by SAP. In contrast, the amount of water retained by common water hyacinth and Late Juncellus remained at $38 \%$ and $33 \%$, respectively, of that retained by SAP.

Table 2. Water-retention capacities of the water-retaining materilas in the laboratoy test

\begin{tabular}{lc}
\hline Water-retaining material & $\begin{array}{c}\text { Amount of water retained } \\
\left(\mathrm{g} \mathrm{g}^{-1}\right)\end{array}$ \\
\hline SAP & $19.3 \mathrm{~B}$ \\
Moss & $21.6 \mathrm{~A}$ \\
Common water hyacinth & $7.4 \mathrm{C}$ \\
Late Juncellus & $6.3 \mathrm{D}$ \\
\hline
\end{tabular}

Different alphabets mean statistical difference at the $1 \%$ level.

\section{Effects of addition of vegetable water-retaining materials on the soil water content and the height of cucumber in comparison with SAP}

The soil water content and the height of cucumber affected by addition of different water-retaining materials are shown in Table 3. In this table, "nothing" means no addition of any water-retaining material to soil. The soil water content after drought stress was higher for the soils with addition of water-retaining materials than for the soil without addition. The soil water content was

Table 3. Effects of the water-retaining materials on the soil water content and the height of cucumber in the pot experiment

\begin{tabular}{lcc}
\hline $\begin{array}{c}\text { Water-retaining } \\
\text { material }\end{array}$ & $\begin{array}{c}\text { Soil water content } \\
\text { after drought } \\
\text { stress } \\
\left(\mathrm{g} \mathrm{kg}^{-1}\right)\end{array}$ & $\begin{array}{c}\text { Height of } \\
\text { cucumber after } \\
\text { cultivation for } 20 \\
\text { days } \\
(\mathrm{cm})\end{array}$ \\
\hline Nothing & $77 \mathrm{c}$ & $7.3 \mathrm{~b}$ \\
SAP & $116 \mathrm{~b}$ & $13.8 \mathrm{a}$ \\
Moss & $168 \mathrm{a}$ & $14.7 \mathrm{a}$ \\
Common water hyacinth & $123 \mathrm{~b}$ & $13.1 \mathrm{a}$ \\
Late Juncellus & $93 \mathrm{bc}$ & $11.9 \mathrm{a}$ \\
\hline
\end{tabular}

Different alphabets mean statistical difference at the $5 \%$ level. significantly different among the water-retaining materials and decreased in the order of moss $>$ common water hyacinth, SAP > Late Juncellus, and no significant effect on the increase of soil water content was noticed to Late Juncellus.

As understood from Table 2, the amount of water retained by common water hyacinth was considerably lower than that by SAP. However, no significant difference was observed in the soil water content after drought stress between them. Because particles of common water hyacinth are smaller than those of SAP, they seem to be more easily and closely mixed with soil particles. As a result, evaporation of water from the soil surface was considered to be more strongly suppressed for common water hyacinth than for SAP.

The height of cucumber was highest for moss, next to SAP, and followed in sequence by common water hyacinth, Late Juncellus and nothing. Addition of water-retaining materials significantly increased the height of cucumber, but no significant difference was recognized in the height of cucumber among the water-retaining materials.

\section{Selection of an appropriate water-retaining mate- rial}

The results shown in Tables 2 and 3 indicate that moss is the best vegetable water-retaining material among the three materials tested in the present study. However, it is difficult to collect moss enough for use as a water-retaining material, and collection of a large amount of moss easily leads to destruction of environment. Therefore, it was considered that moss had a high potential but actually was not appropriate for using as a water-retaining material in crop production.

Common water hyacinth is an invading aquatic macrophyte with a potential for rapid growth and spreading, and has caused serious damage to local environment. If common water hyacinth can be used as a vegetable water-retaining material, it not only mitigates damage of crops due to drought but also solves the problem induced by its adverse effects on the environment. The water-retention capacity of common water hyacinth was inferior to that of moss, but the function of common water hyacinth on keeping the soil water content after drought stress and improving the height of cucumber was not significantly different from the function of SAP. Therefore, common water hyacinth was selected as an appropriate and actual vegetable water-retaining material and tested in the following experiment (Part 2) on the effects on the growth and quality of cucumber.

\section{CONCLUSIONS}

In order to reduce the damage of crops due to seasonal drought occurring in Guangxi Province and to prevent environment from pollution caused by the longterm use of artificial chemical compounds, three kinds of aquatic plants were tested on the function as a waterretaining material in the effects on the soil water content and the growth of cucumber. Moss was potentially high- 
est in the function as a water-retaining material. However, common water hyacinth was regarded as an appropriate and actual water-retaining material in the crop production.

\section{ACKNOWLEDGEMENTS}

A part of this research was financially supported by the Guangxi University Technology Development Fund. The authors express their sincere thanks to the financial support by the Fund.

\section{REFERENCES}

Committee of Guangxi Soil Investigation Group 1994 Soils of Guangxi Province. Science and Technology Publisher,
Guangxi (China) (in Chinese)

Committee of Standard Methods for Analysis and Measurement of Soil (ed) 1986 Standard Methods for Analysis and Measurement of Soil. Hakuyusha, Tokyo (Japan) (in Japanese)

Li, Y. -X., X. -C. Li, Y. -Q. Zhang and F. -X. Tu 2001 Analysis and prevention of the damage of drought in Guangxi. Journal of Guangxi Agricultural Science, 3: 113-117 (in Chinese)

Sun, J., Y. -C. Xu, Q. -R. Shen and Y. -B. Wang 2001 Effects of rice mulch and water-retaining agent on soil properties and crop yield. Chinese Journal of Applied Ecology, 5: 731734 (in Chinese)

Yang, S. -D., R. Wang, G. Li and K. Egashira 2008 Selection of a vegetable water-retaining material and its effects on the growth and quality of cucumber under drought stress. Part 2: Effects of common water hyacinth on the growth and quality of cucumber. Journal of the Faculty of Agriculture, Kyushu University, 53: in press 